\title{
EVALUATION OF GLASS AS A MATRIX FOR SOLIDIFICATION OF SAVANNAH RIVER PLANT WASTE
}

\author{
NONRADIOACTIVE AND TRACER STUDIES
}

\author{
J. A. KELLEY
}

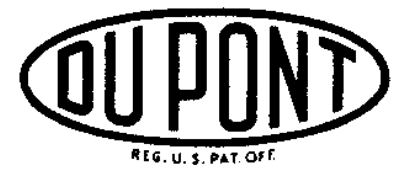

E. I. du Pont de Nemours \& Co.

Savannah River Laboratory

Aiken, S. C. 29801 


\section{NOTICE}

This report was prepered as an account of work sponsored by the United States Government. Neither the United States nor the United States Energy Research and Development Administration, nor any of their contractors, subcontractors, or their employees, makes any warranty, express or implied, or assumes any legal liability or responsibility for the accuracy, completeness or usefulness of any information, apparatus, product or process diselosed, or represents that its use would not infringe privately owned rights.

Printed in the United States of America

Available from

National Technical Information Service

U. S. Department of Commerce

5285 Port Royal Road

Springfield, Virginia 22161

Price: Printed Copy \$4.00; Microfiche \$2.25 


\title{
663034
}

DP-1382

(Distribution Category UC-70)

\section{EVALUATION OF GLASS AS A MATRIX FOR SOLIDIFICATION of SAVANNAH RIVER PLANT WASTE}

\author{
NONRADIOACTIVE AND TRACER STUDIES
}

\author{
J. A. Kelley
}

\section{Approved by}

W. H. Hale, Jr., Research Manager

Separations Chemistry Division

Publication Date: May 1975
E. 1. du Pont de Nemours \& Co.
Savannah River Laboratory
Aiken, S. C. 29801

PREPARED FOR THE U. S. ENERGY RESEARCH AND DEVELOPMENT ADMINISTRATION UNDER CONTRACT AT(07-2)-I 


\section{ABSTRACT}

One option for 1ong-term management of Savannah River P1ant high-activity waste is solidification and storage in a retrievable surface storage facility to be located on the plantsite. This study demonstrated that SRP waste can be incorporated into a borosilicate glass at $1150^{\circ} \mathrm{C}$.

Tests with simulated waste indicate that alkaline sludge stored in SRP waste tanks can be solidified in borosilicate glass containing up to $45 \mathrm{wt} \%$ sludge. For melting at $1150^{\circ} \mathrm{C}$, the optimum glass mixture is $52.5 \mathrm{wt} \% \mathrm{SiO}_{2}, 10.0 \% \mathrm{~B}_{2} \mathrm{O}_{3}, 22.5 \%$ $\mathrm{Na}_{2} \mathrm{O}, 5.0 \% \mathrm{CaO}$, and $10.0 \% \mathrm{TiO}_{2}$.

Aluminum increases glass melt viscosity and can limit the amount of sludge solidified. Sulfate has limited solubility; above 0.8 to $1.0 \mathrm{wt} \%$ sulfate, a separate, water-soluble, cesiumrich phase is formed.

During melting, $20.5 \%$ of the cesium, 10 to $50 \%$ of the ruthenium, and all of the mercury present in the giass mixture are volatilized.

At $25^{\circ} \mathrm{C}$, initial leachabilities for both ${ }^{137} \mathrm{Cs}$ and ${ }^{85} \mathrm{Sr}$ are $\sim 10^{-6} \mathrm{~g} /\left(\mathrm{cm}^{2}\right.$-day $)$ and both decrease to $\sim 10^{-8} \mathrm{~g} /\left(\mathrm{cm}^{2}-\right.$ day $)$ after 40 days.

Gamma irradiation to $10^{10}$ rads and alpha decay in the glass matrix do not significantly affect the glass waste forms.

Devitrification of waste glasses occurs near $600^{\circ} \mathrm{C}$, but leachability is increased by only a factor of $\sim 3$. 


\section{CONTENTS}

Page

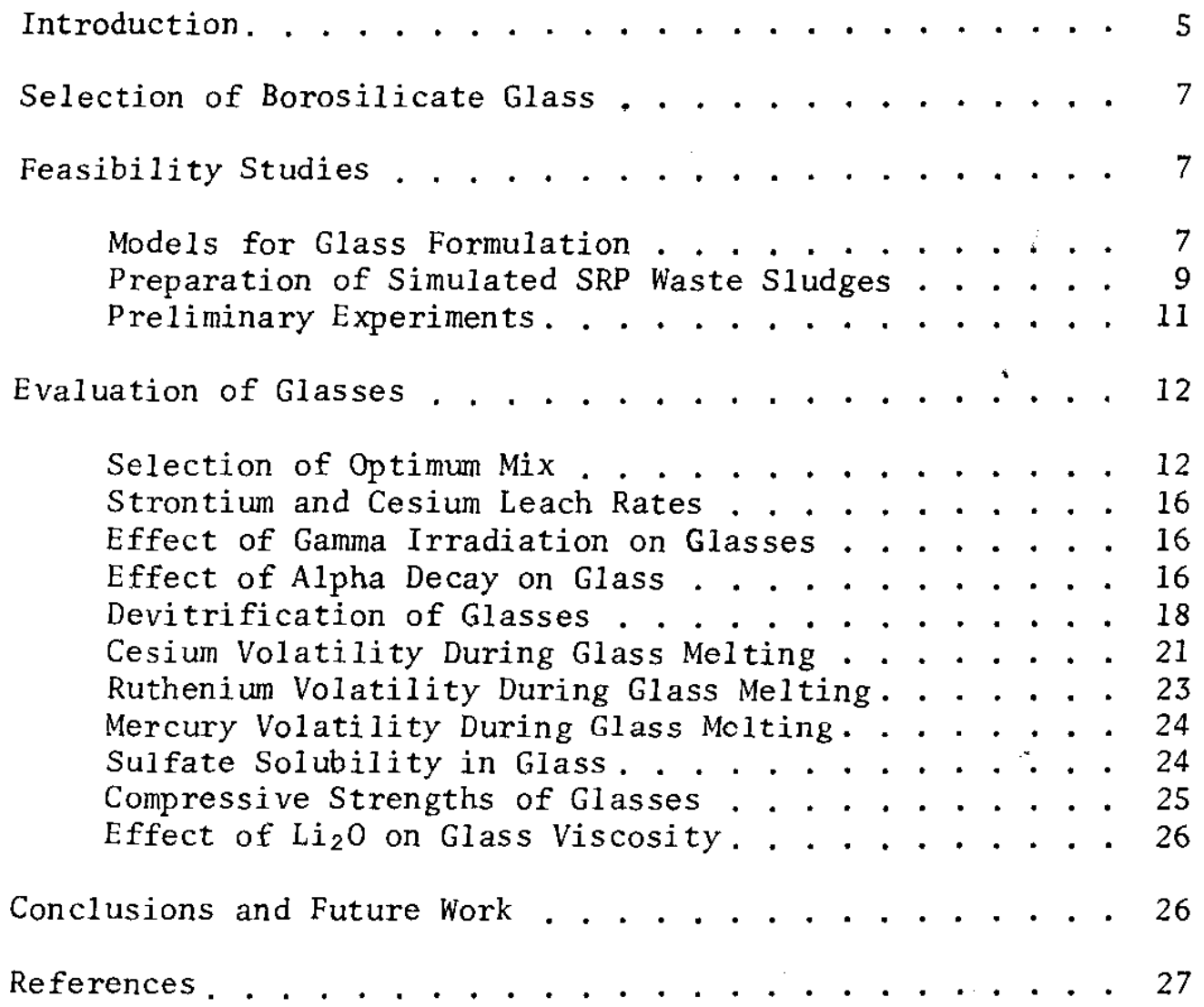




\title{
EVALUATION OF GLASS AS A MATRIX FOR SOLIDIFICATION OF SAVANNAH RIVER PLANT WASTE
}

\author{
NONRADIOACTIVE AND TRACER STUDIES
}

\section{INTRODUCTION}

Studies are in progress at the Savannah River Laboratory (SRL) to determine methods for possible solidification and storage of Savannah River Plant (SRP) high-level liquid radioactive waste. In one of several options under consideration, solidified waste would be stored in an on-site, retrievable surface storage facility until the waste could be shipped to a federal repository.

An earlier report ${ }^{1}$ described in detail the origins and characteristics of SRP waste, the criteria for acceptable solid forms, and potential solid forms for SRP waste. That study was used to formulate the conceptual process shown in Figure 1.

SRP waste, stored in underground tanks, consists of an alkaline salt solution, solid salt cake, and an insoluble sludge layer containing large amounts of iron, aluminum, manganese, and many other elements. In the conceptual process, waste would be removed from a tank by dissolving the salt cake with water and sluicing the slurry of sludge and solution from the tank. Sludge and solution would be separated by centrifugation and filtration.

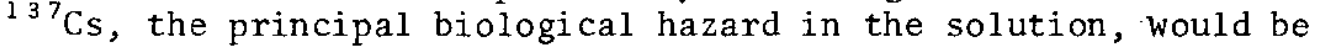
removed by an ion exchange process and sorbed onto zeolite. SIudge would be washed to remove salts, dried, and blended with the cesiumzeolite for solidification into either concrete or glass. The mass of sludge would be much greater than that of cesium-zeolite, so that sludge is the controlling factor in solidification process chemistry. In this report, the feasibility of incorporating simulated, non radioactive SRP waste into borosilicate glas is demonstrated. Studies of the vitrification of actual SRP waste will be described in a subsequent report. Studies of waste removal from tanks, separation of sludge and salt solution, removal of radionuclides from salt solution, and solidification of waste in concrete will also be described in other reports. 


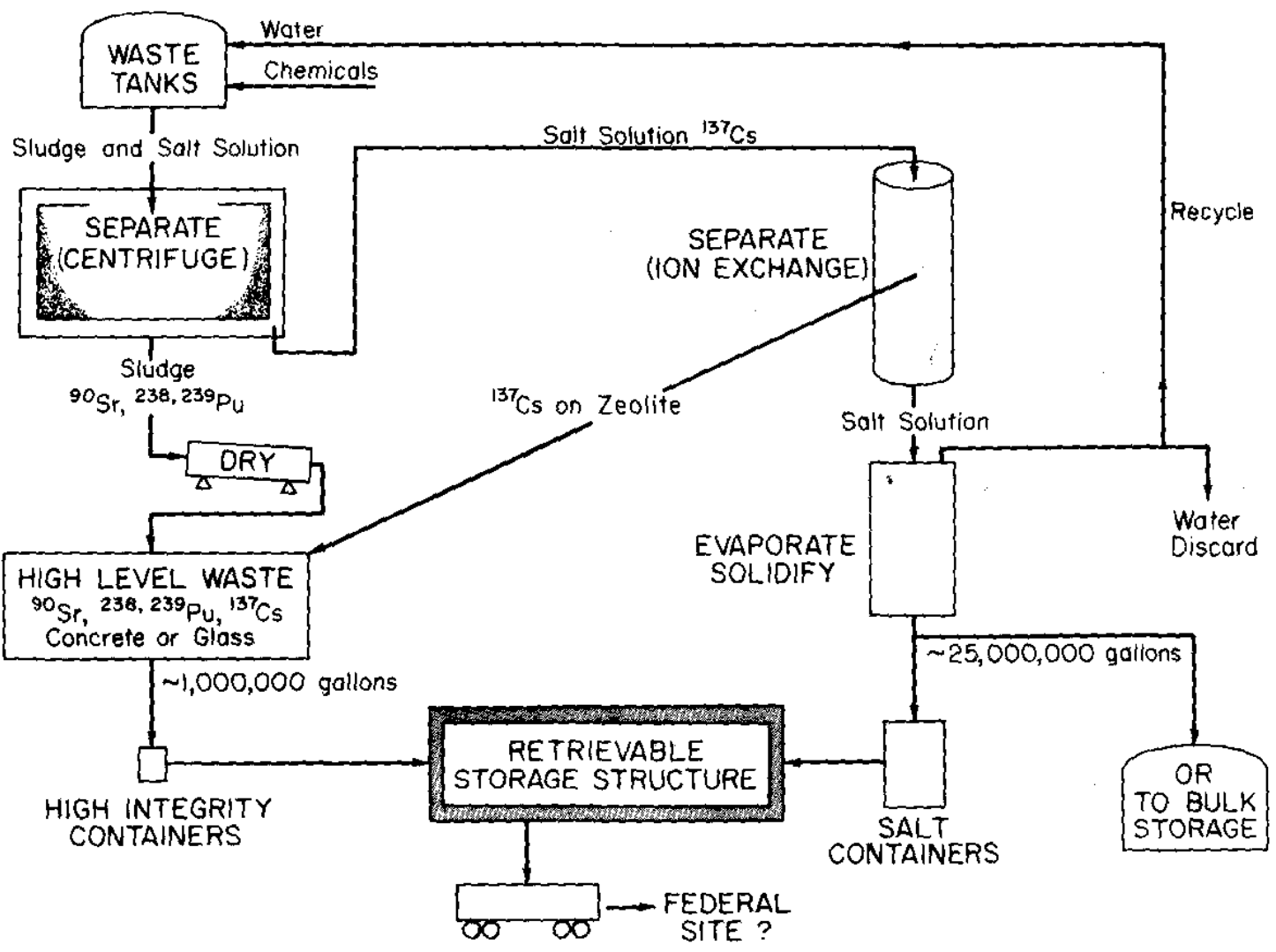

FIGURE 1. Conceptual Waste Solidification Process 


\section{SELECTION OF BOROSILICATE GLASS}

Most glasses have sufficient mechanical strength and radiation stability for solidification of SRP high-leve1 waste. High thermal conductivity is inherent to most glasses but is not crucial for SRP waste because of its low power density. Under accident conditions, a low leach rate is probably the most important attribute of a glass waste form.

Processes for the solidification of radioactive waste into phosphate and borosilicate glasses have been developed. However, phosphate glasses devitrify with a 1000-fold increase in leach rate. ${ }^{2}$ On the other hand, devitrified borosilicate glasses are only slightly more leachable than amorphous glasses (Figure 2). Because of this, phosphate glasses were not considered acceptable as solid matrices for long-term storage of SRP wastes.

A number of borosilicate glass processes have been developed for solidification of radioactive wastes. ${ }^{3-4}$ In most of these processes, $\mathrm{SiO}_{2}, \mathrm{~B}_{2} \mathrm{O}_{3}, \mathrm{CaO}, \mathrm{Na}_{2} \mathrm{O}$, and other selected additives are blended with radioactive wastes, causing fission products, corrosion products, and other chemicals from fuel reprocessing to be added. The mixture is melted at 1050 to $1250^{\circ} \mathrm{C}$. Leach abilities of most vitreous products are $10^{-5}$ to $10^{-7} \mathrm{~g} /\left(\mathrm{cm}^{2}-\right.$ day $)$. The composition of the glass mix blended with waste to form the final product depends on the composition of waste. For example, wastes with high sodium content require a low-sodium glass mix to ensure that the product does not contain excess sodium. The glass mix composition may also be affected by other elements in waste.

\section{FEASIBILITY STUDIES}

Theoretical models ${ }^{3,4}$ were used to estimate appropriate compositions of borosilicate glass for SRP waste. Preliminary studies with simulated sludge indicated that borosilicate glasses of high sludge content could be made.

\section{Models for Glass Formulation}

Glasses are composed of network formers and network modifiers. Silicon, boron, and aluminum are network formers because they bond to oxygen and form an extended network. Aluminum and boron lower the melting temperature, increase chemical stability (as measured by leach tests), and slow the rate of devitrification of glass. Too much aluminum and boron in glass make the viscosity 


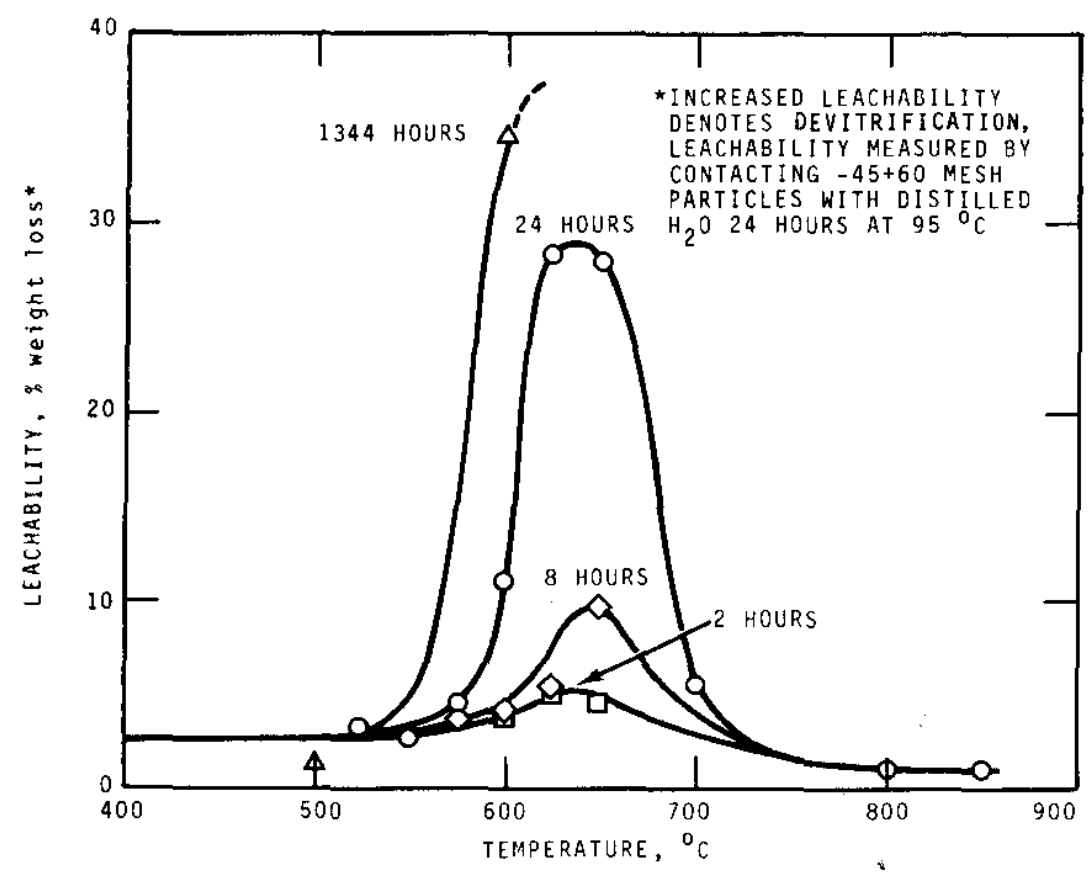

Phosphate Glass

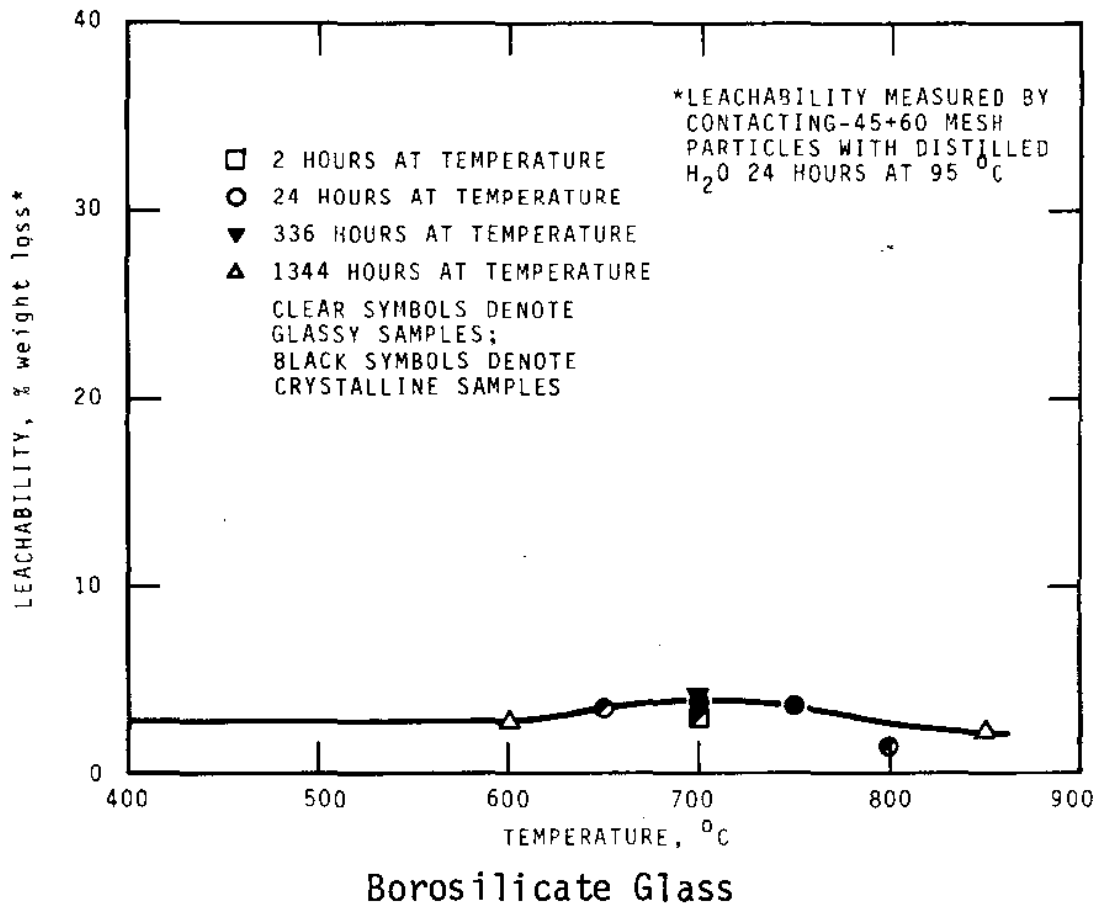

FIGURE 2. Devitrification of Phosphate and Borosilicate Glasses (from Reference 2, p. 5.9) 
of the melt too high. Other elements used in glass formation, such as sodium, potassium, calcium, and sludge components, fit into interstices of the glass network and are called network modifiers. $\mathrm{Na}_{2} \mathrm{O}$ and $\mathrm{K}_{2} \mathrm{O}$ lower the melting temperature of glass, but too much of either reduces chemical stability.

Two semi-empirical studies ${ }^{3,4}$ resulted in guidelines for formulation of acceptable glasses. The important atom ratios of glass components are:

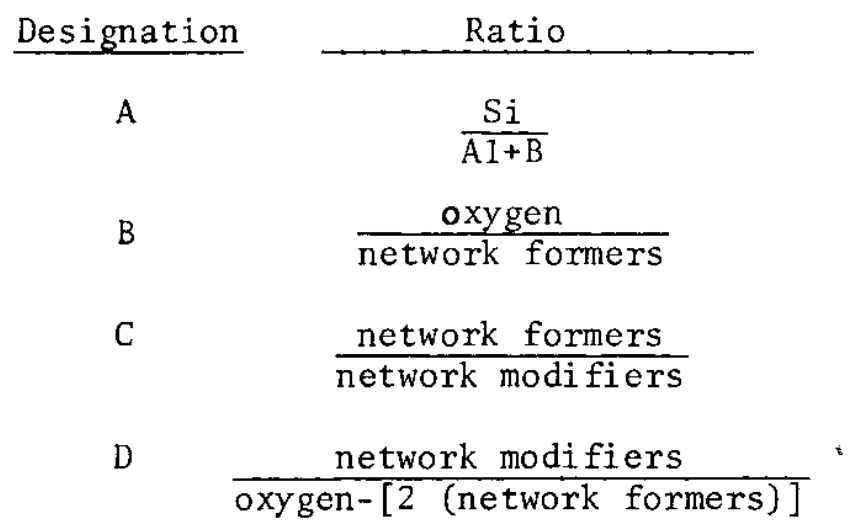

When Ratio A is $>1.5$, leachability is low. Melting point of glass increases as $\mathrm{A}$ increases. With Ratio $\mathrm{B}$ between 2.2 and 2.4, glass formation is best and leachability is low. Excess oxygen is needed to balance the electronic charge of network modifiers. Density increases as A decreases and B increases. Ratio $C$ should be $\sim 2$ for good glass formation. As $C$ decreases, the glass network is disrupted and the tendency for glass formation decreases. Ratio D represents the ratio of network. modifiers to excess oxygen not required for network formers to be four-coordinate. D should be as near as possible to 2 .

A model developed at the Hahn-Meitner Institute ${ }^{5}$ uses the formula in Table 1 for determining optimum glass composition. The suggested glass composition is $4 \mathrm{~mol} \mathrm{SiO}_{2} / 2 \mathrm{~mol} \mathrm{~B}_{2} \mathrm{O}_{3} / 1 \mathrm{~mol}$ $\mathrm{Al}_{2} \mathrm{O}_{3} / 2 \mathrm{~mol} \mathrm{CaO} / 1$ or $3 \mathrm{~mol} \mathrm{Na}_{2} \mathrm{O}$ plus 20 wt $\%$ waste.

\section{Preparation of Simulated SRP Waste Sludges}

Since waste sludge composition can vary markedly from tank to tank, three types of simulated sludges were prepared on the basis of plant processes and some preliminary sludge analyses. These three compositions (Table 2) are expected to cover the range of compositions to be encountered with actual waste. Nonradioactive strontium was added for subsequent leach testing because strontium and plutonium are the principal biological hazards in sludge. 
In early work, preparing small $1 \mathrm{ab}-\mathrm{scale}$ batches of simulated sludge was found to be tedious and time-consuming, and sludge properties varied from batch to batch. Because of this, 50-1b batches of simulated sludges were prepared in largescale equipment. This ensured that variations in results would not be caused by variations in sludge starting material.

TABLE 1

Hahn-Meitner Institute Model

$(10-2 \mathrm{X}-2 \mathrm{Y}) \mathrm{SiO}_{2} / \mathrm{XB}_{2} \mathrm{O}_{3} / \mathrm{YAl}_{2} \mathrm{O}_{3} / 2 \mathrm{CaO} / 1$ or $3 \mathrm{Na}_{2} \mathrm{O}$

$Y=0.5$ to $1.0 ; \mathrm{m} \cdot \mathrm{p} .=1100-1200^{\circ} \mathrm{C}$

$X=\imath 2$ with $Y>0.5$

Suggested glass composition:

$4 \mathrm{SiO}_{2} / 2 \mathrm{~B}_{2} \mathrm{O}_{3} / 1 \mathrm{Al}_{2} \mathrm{O}_{3} / 2 \mathrm{CaO} / 1$ or $3 \mathrm{Na}_{2} \mathrm{O}$

plus

20 wt \% waste

TABLE 2

Simulated SRP Waste Sludges

Sludge I: $\quad 50 \% \mathrm{Fe}(\mathrm{OH})_{3}, 50 \% \mathrm{AL}(\mathrm{OH})_{3}$

Sludge II: $\quad 40 \% \mathrm{Fe}(\mathrm{OH})_{3}, 40 \% \mathrm{Al}(\mathrm{OH})_{3}, 20 \% \mathrm{HgO}$

Sludge III: $50 \% \mathrm{Fe}(\mathrm{OH})_{3}, 50 \% \mathrm{MnO}_{2}$

All contain $400 \mathrm{ppm} \mathrm{Sr}$ 


\section{Preliminary Experiments}

Twelve glass formulations were prepared with Type III simulated sludge. Table 3 shows the glass compositions and calculated atom ratios. Formulation 5 contained all atom ratios in the range specified by the mode $1 .{ }^{3,4}$ The glass components were mixed as dry solids. Boric acid supplied $\mathrm{B}_{2} \mathrm{O}_{3}$, and $\mathrm{Na}_{2} \mathrm{CO}_{3}$ supplied $\mathrm{Na}_{2} \mathrm{O}$. Titanium in Formulation 8 reduces volatility of cesium. ${ }^{6}$ The formulations were heated at 850 to $900^{\circ} \mathrm{C}$ in either porcelain or graphite crucibles for $\imath_{1} \mathrm{hr}$ to remove $\mathrm{II}_{2} \mathrm{O}$ and $\mathrm{CO}_{2}$, heated in a furnace at 1200 to $1275^{\circ} \mathrm{C}$ for $1 \mathrm{hr}$, transferred to a furnace at $\sim 400^{\circ} \mathrm{C}$ for $1 \mathrm{hr}$, and cooled to ambient temperature. Test results are shown in Table 4. Formulations 5-10 formed homogeneous, dark brown glasses, with densities of 2.47 to $2.84 \mathrm{~g} / \mathrm{cm}^{3}$.

These preliminary tests showed that simulated waste sludge could be incorporated into glass and that models used to determine relative amounts of glass components are valid. Although the models are not exact, they provide useful guidelines. On the basis of these preliminary tests, a more thorough study was begun of the solidification of SRP waste sludge in borosilicate glass.

TABLE 3

Compositions and Atom Ratios of Borosilicate Glasses Containing Simulated Sludge

\begin{tabular}{|c|c|c|c|c|c|c|c|}
\hline \multirow{2}{*}{$\begin{array}{c}\text { Mix } \\
\text { Formuza }\end{array}$} & \multicolumn{7}{|c|}{ Mix Composition, wt \% } \\
\hline & $\mathrm{SiO}_{2}$ & $\underline{\mathrm{B}_{2} \mathrm{O}_{3}}$ & $\mathrm{Az}_{2} \mathrm{O}_{3}$ & $\mathrm{Na}_{2} \mathrm{O}$ & $\underline{\mathrm{CaO}}$ & $\mathrm{TiO}_{2}$ & szudge III \\
\hline 1 & $75^{a}$ & - & - & - & - & - & 25 \\
\hline 2 & $65^{a}$ & 10 & - & - & - & - & 25 \\
\hline $3^{b}$ & 61 & 9.5 & 1.5 & 3 & - & - & 25 \\
\hline $4 c$ & 59 & 11.5 & 1.5 & 3 & - & - & 25 \\
\hline $5^{d}$ & 50 & 15 & - & 10 & - & - & 25 \\
\hline $6^{e}$ & 28.8 & 12.8 & 12 & 8 & 17.6 & - & 20 \\
\hline $7 f$ & 38 & 22 & 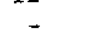 & 8 & 12 & - & 20 \\
\hline $8^{9}$ & 42 & 8 & 2 & 16 & 4 & 8 & 20 \\
\hline 9 & 40 & 15 & 10 & 10 & - & - & 25 \\
\hline 10 & 30 & 15 & 10 & 10 & 10 & - & 25 \\
\hline $11^{h}$ & & & & & & & 25 \\
\hline $12^{i}$ & & 10 & & & & & 25 \\
\hline
\end{tabular}

\begin{tabular}{lcccc}
\multicolumn{4}{c}{ Atom Ratios } \\
\cline { 1 - 2 } & \multicolumn{1}{c}{$B$} & C & D \\
\cline { 5 - 5 } & & 2.35 & 3.83 & 0.75 \\
3.76 & 2.21 & 4.20 & 1.12 \\
3.35 & 3.25 & 3.11 & 1.28 \\
2.72 & 2.23 & 3.32 & 1.33 \\
1.93 & 2.30 & 1.94 & 1.72 \\
0.79 & 2.45 & 1.30 & 1.70 \\
1.00 & 2.30 & 1.72 & 1.95 \\
2.57 & 2.77 & 1.02 & 1.28 \\
1.06 & 2.22 & 1.99 & 2.31 \\
0.79 & 2.41 & 1.36 & 1.80 \\
- & - & - & - \\
- & - & - & -
\end{tabular}

\footnotetext{
a. Sea sand

b. Corning 7740 glass + sludge

c. Corning 7740 glass $+2 \% \mathrm{~B}_{2} \mathrm{O}_{3}+$ sludge

d. "I deal" composition based on model

e. Hahn-Meitner Institute formulation ${ }^{5}$

f. Jilich formulation ${ }^{7}$

g. Karlsruhe formulation ${ }^{7}$

h. Plant soil near Laboratory, $75 \mathrm{wt} \%$

$i$. Same as $h, 65$ wt $\%$.
} 
TABLE 4

Properties of Glasses for Sludge Incorporation

$\begin{aligned} \text { Formulation } & \text { Glass Quality } \\ 1 & \text { Poor; sti11 granular } \\ 2 & \text { Poor; "honeycomb" appearance } \\ 3 & \text { Fair; inhomogeneous } \\ 4 & \text { Fair; inhomogeneous } \\ 5 & \text { Good; dark brown } \\ 6 & \text { Good; dark brown } \\ 7 & \text { Good; dark brown } \\ 8 & \text { Good; dark brown } \\ 9 & \text { Good; dark brown } \\ 10 & \text { Good; dark brown } \\ 11 & \text { Poor; stil1 granular } \\ 12 & \text { Poor }\end{aligned}$

$\begin{array}{cc}\begin{array}{c}\text { Glass Density, } \\ \text { g/ } \mathrm{cm}^{3}\end{array} & \begin{array}{c}\text { Formation, } \\ { }^{\circ} \mathrm{C}\end{array} \\ - & \\ - & 1275 \\ - & 1275 \\ - & 1275 \\ 2.63 & 1275 \\ 2.57 & 1200 \\ 2.84 & 1200 \\ 2.71 & 1200 \\ 2.47 & 1200 \\ 2.63 & 1200 \\ - & 1275 \\ - & 1275 \\ & 1275\end{array}$

EVALUATION OF GLASSES

Tests were conducted with Sludges I and III to define the optimum glass mix for future studies with actual waste. Sludge I I was used only in mercury volatilization tests. Selection of the optimum mix was based on sludge content, leach rates, melt viscosity, and product homogeneity. Further tests were conducted with the optimum mix to determine strontium and cesium leach rates, the effects of gamma radiation and alpha decay on the glass products, possible effects of devitrification, volatility of cesium, ruthenium, and mercury during melting, sulfate solubility, the effect of $\mathrm{Li}_{2} \mathrm{O}$ on melt viscosity, and compressive strength of the glasses.

\section{Selection of Optimum Mix}

Tables 3 and 5 show compositions of glass mixes used to incorporate simulated sludges. (Mixes 1 through 4 and 11 through 13 did not form good glasses.) For reference, the compositions of Coming 7740 Pyrex (Registered trademark of Corning Glass Works) and National Bureau of Standards $710 \mathrm{glasses}$ are also given.

A11 glasses were melted at $1150^{\circ} \mathrm{C}$ for $3 \mathrm{hr}$, annealed at $\checkmark 500^{\circ} \mathrm{C}$ for $1 \mathrm{hr}$, and then allowed to cool to ambient temperature in the annealing furnace. With $>50 \mathrm{wt} \%$ Sludge III, the products were granular and unacceptable. With $>35 \mathrm{wt} \%$ SIudge $\mathrm{I}$, the glass melt was too viscous (because of aluminum) for easy pouring. 
TABLE 5

Compositions of Borosilicate Glass Mixes, wt \%

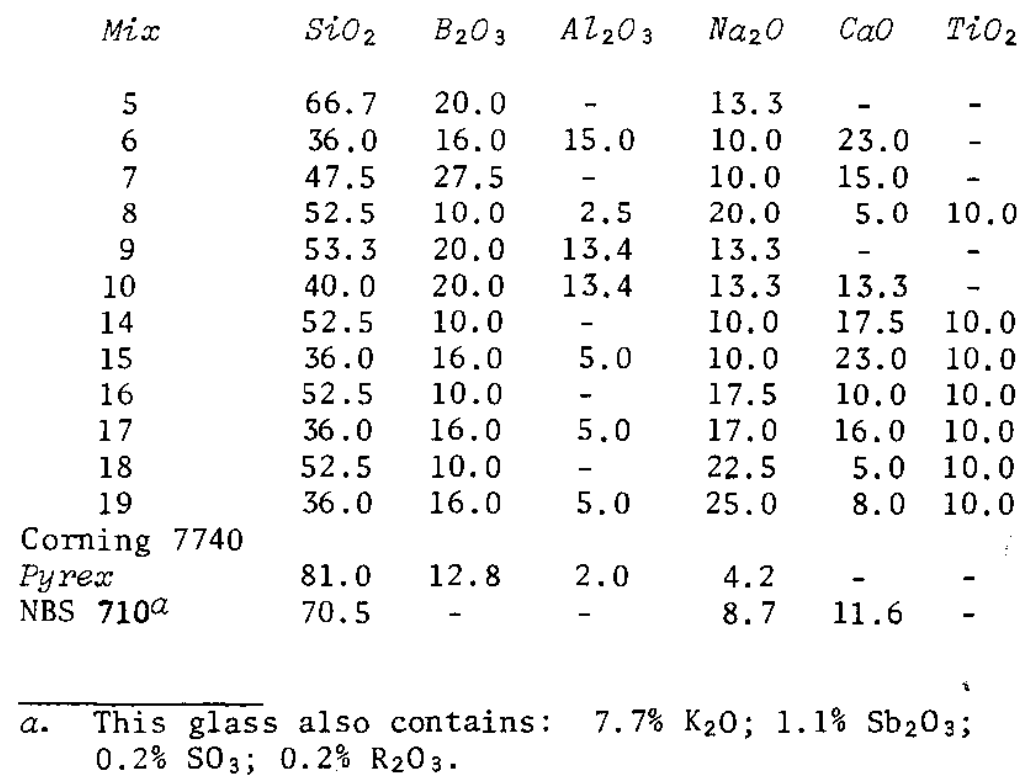

Glasses prepared in this manner from Sludges I and III were characterized in leach tests (Table 6). 8 to $12 \mathrm{~g}$ of the test glass was crushed, sieved to 0.25-0.08 in. (10 mesh), washed with acetone to remove fines, dried, weighed, and leached for $24 \mathrm{hr}$ at $\sim 99^{\circ} \mathrm{C}$ in a Soxhlet extractor (Figure 3). The leached glass was reweighed, and leach solutions were analyzed for sodium by atomic absorption and for strontium by emission spectroscopy. Bulk leach rates were calculated by dividing the fractional weight loss, or fraction of sodium or strontium leached by the product of the specific surface area of the crushed glass and the time leached. Surface area of crushed glass, 0.25 to 0.08 in., as measured by the B.E.T. method using krypton, was $41 \mathrm{~cm}^{2} / \mathrm{g}$.

Sodium leachability generally increased as sludge content increased, which was expected because sludge contains network modifiers (iron and manganese) that disrupt the glass framework. Sodium leachabilities for glasses with Sludge I were less than those for Sludge III for similar loadings because Sludge I contains $50 \mathrm{mo} 1 \% \mathrm{Al}(\mathrm{OH})_{3}$ (a network former).

Strontium leachability was generally less than that of sodium. Wider apparent variations in strontium leaching are attributed to analytical limitations at low concentrations ( $\sim 0.01$ ppm). 
TABLE 6

Soxhlet Leach Tests, $24 \mathrm{hr}$ at $\sim 99^{\circ} \mathrm{C}$

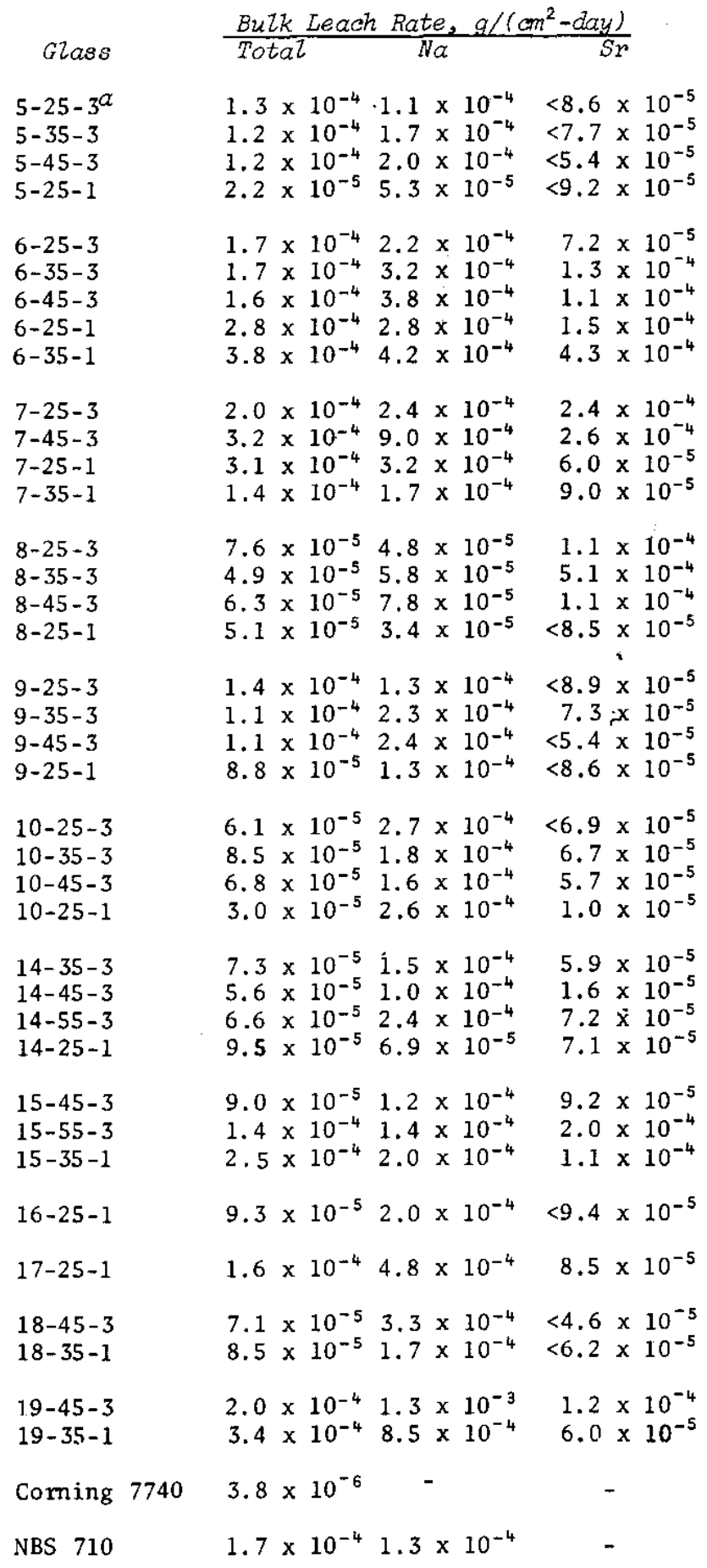

a. 5 is mix number; 25 is wt $\%$ sludge; 3 is Sludge III. 


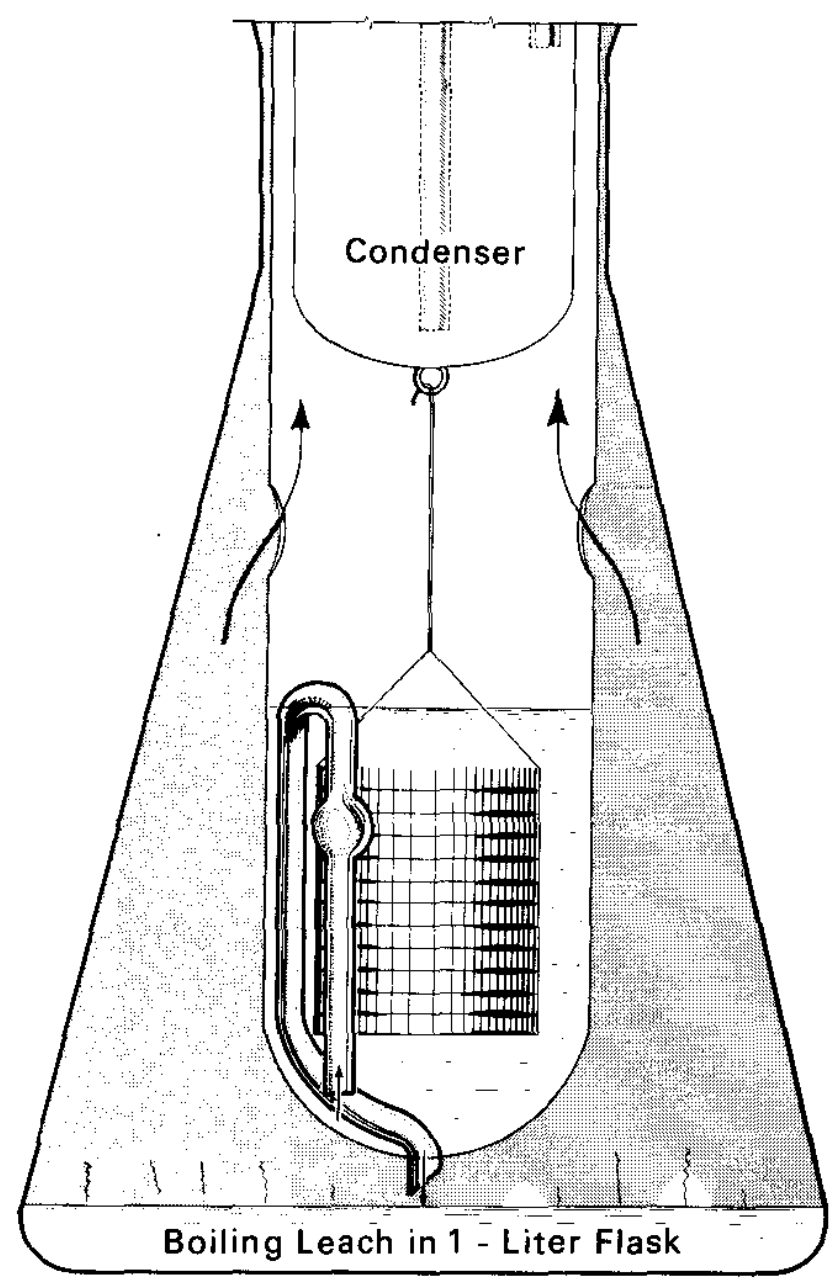

FIGURE 3. Leaching Extractor for Glass

For comparison, Corning 7740 Pyrex glass and National Bureau of Standards Glass 710 were leached by the method described above. The leachabilities of the sludge-containing glasses are similar to, and in some cases lower than, the National Bureau of Standards soda-lime-silica glass.

Mix 18 had the best combination of desirable properties and was selected for further testing.

A test was also made to demonstrate that cesium-zeolite can be incorporated into borosilicate glass. A glass containing $50 \mathrm{wt} \%$ zeolite (Na-form chabazite) was melted at $1150^{\circ} \mathrm{C}$ and annealed at $\sim 500^{\circ} \mathrm{C}$. The product contained 24.0 wt $\% \mathrm{SiO}_{2}, 9.8 \% \mathrm{Al}_{2} \mathrm{O}_{3}, 24.2 \% \mathrm{~B}_{2} \mathrm{O}_{3}, 17.8 \%\left(\mathrm{Na}_{2} \mathrm{O}, 12.1 \% \mathrm{CaO}\right.$, and $12.1 \% \mathrm{TiO}_{2}$. Under the same leaching conditions as for the 
sludge glasses, the leach rate based on weight loss was $3.3 \mathrm{x}$ $10^{-4} \mathrm{~g} /\left(\mathrm{cm}^{2}-\right.$ day $)$ at $99^{\circ} \mathrm{C}$.

\section{Strontium and Cesium Leach Rates}

Because extrapolating high-temperature leach data to ambient temperature is difficult, glasses were prepared with tracer amounts of ${ }^{137} \mathrm{Cs}$ and ${ }^{85} \mathrm{Sr}$ and leached at anbient temperature to obtain more-accurate leach rates.

Glasses containing $35 \mathrm{wt} \%$ Sludge I and $45 \mathrm{wt} \%$ Sludge III, each containing ${ }^{137} \mathrm{Cs}$ and ${ }^{85} \mathrm{Sr}$ were prepared with $\mathrm{Mix} 18$, which has a low leach rate, contains titanium for cesium retention, and has a low melting temperature.

These glasses (designated as 18-35-1 and 18-45-3 for Mix 18, w' $\%$ sludge, and sludge type) were crushed and sieved to $0.25-0.08$ in. and leached in stirred distilled water at ambient temperature $\left(\sim 25^{\circ} \mathrm{C}\right)$. Leach solutions were analyzed for ${ }^{137} \mathrm{Cs}$ and ${ }^{85} \mathrm{Sr}$ by low-level gamma counting. Leachabilities (Table 7) were calculated as before. These data confirm the preliminary tests showing that simulated SRP waste sludges can be incorporated into a low-leachable glass.

\section{Effect of Gamma Irradiation on Glasses}

Glasses containing actual SRP waste sludge would be exposed to $\sim 10^{10}$ rads of gamma radiation in $100 \mathrm{yr}$ of storage. The effect of such exposure was evaluated by irradiating crushed and monolithic samples of glasses $18-35-1$ and $18-45-3$ with ${ }^{60} \mathrm{Co}$ to $10^{10}$ rads at $\sim 65^{\circ} \mathrm{C}$. No changes in leachabilities or appearance were observed. These results were not unexpected because borosilicate glasses have been irradiated to $10^{11}$ rads without significant effects. ${ }^{8}$

\section{Effect of Alpha Decay on Glass}

Little is known of the effect of helium accumulation from alpha decay of actinides in glass waste forms. Normal borosilicate glasses have a high permeability or diffusivity and can be saturated with gas at several thousand psi without damaging the glass when the pressure is released. ${ }^{9}$ However, incorporation of network modifiers may decrease permeability or diffusivity, so that decay helium may not be able to escape before generating sufficient stress to damage the glass. The magnitude of these stresses required to damage glass have not been measured, 10 but a critical stress of 1000 psi has been 
estimated from measured tensile strengths of borosilicate glass ( $930 \mathrm{psi}){ }^{11}$

Two glasses, one containing 0.5 wt $\%{ }^{244} \mathrm{Cm}$ and the other 1 wt $\% 2{ }^{3} \mathrm{Pu}$, were prepared with Mix 18 containing $45 \%$ sludge II I (Glass 18-45-3). Properties of the glasses are sumarized in $\mathrm{T}$ able 8 .

TABLE 7

Leach Rates for Glasses $18-35-1$ and $18-45-3$ at $25^{\circ} \mathrm{C}$

\begin{tabular}{|c|c|c|c|c|}
\hline \multirow[b]{2}{*}{ Leach Time, days } & \multicolumn{4}{|c|}{ Leachability, $g / \mathrm{cm}^{2}-d a y$} \\
\hline & $\overline{18-35-1}$ & $18-45-3$ & $\overline{18-35-1}$ & $18-45-3$ \\
\hline 1 & $1.9 \times 10^{-6}$ & $2.8 \times 10^{-6}$ & $2.66 \times 10^{-6}$ & $1.02 \times 10^{-6}$ \\
\hline 4 & $1.07 \times 10^{-5}$ & $5.49 \times 10^{-7}$ & $1.23 \times 10^{-6}$ & $2.04 \times 10^{-7}$ \\
\hline 7 & $1.88 \times 10^{-7}$ & $4.12 \times 10^{-7}$ & $2.74 \times 10^{-7}$ & $1.52 \times 10^{-7}$ \\
\hline 11 & $6.11 \times 10^{-7}$ & $7.85 \times 10^{-7}$ & $5.69 \times 10^{-7}$ & $2.72 \times 10^{-7}$ \\
\hline 16 & $8.06 \times 10^{-7}$ & $6.90 \times 10^{-7}$ & $8.32 \times 10^{-7}$ & $2.21^{*} \times 10^{-7}$ \\
\hline 21 & $8.23 \times 10^{-7}$ & $1.27 \times 10^{-6}$ & $4.94 \times 10^{-7}$ & $4.83 \times 10^{-7}$ \\
\hline 42 & $1.58 \times 10^{-8}$ & $7.42 \times 10^{-8}$ & $4.91 \times 10^{-8}$ & $1.43 \times 10^{-8}$ \\
\hline 49 & $1.04 \times 10^{-8}$ & $2.09 \times 10^{-7}$ & $1.45 \times 10^{-8}$ & $3.42 \times 10^{-8}$ \\
\hline 64 & $2.77 \times 10^{-8}$ & $7.34 \times 10^{-8}$ & $1.90 \times 10^{-8}$ & $1.25 \times 10^{-8}$ \\
\hline 72 & $2.87 \times 10^{-8}$ & $7.14 \times 10^{-8}$ & $9.07 \times 10^{-9}$ & $1.03 \times 10^{-8}$ \\
\hline 78 & $1.71 \times 10^{-8}$ & $7.80 \times 10^{-8}$ & $1.21 \times 10^{-8}$ & $1.69 \times 10^{-8}$ \\
\hline 93 & $6.29 \times 10^{-8}$ & $8.10 \times 10^{-8}$ & $3.32 \times 10^{-8}$ & $1.29 \times 10^{-8}$ \\
\hline & $3.65 \times 10^{-8}$ & $6.82 \times 10^{-8}$ & $1.94 \times 10^{-8}$ & $8.76 \times 10^{-8}$ \\
\hline
\end{tabular}

TABLE 8

Properties of Waste Glass Forms Containing ${ }^{244} \mathrm{Cm}$ or ${ }^{238} \mathrm{Pu}$

$\begin{array}{lcc} & { }^{244} \mathrm{Cm} & { }^{23{ }^{8}} \mathrm{Pu} \\ \text { Glass, grams } & 16.4 & 14.5 \\ { }_{244} \mathrm{Cm} \text { or } 23 \mathrm{Pu}_{3} \mathrm{mg}^{a} & 81 & 140 \\ \begin{array}{l}\text { Density, g/(cm } \\ \text { Alpha dose rate, }\end{array} & 3.047 & 3.116 \\ \begin{array}{l}1^{12} \text { particles } /\left(\mathrm{cm}^{3}\right) \text { (min) } \\ 12.7\end{array} & 2.0\end{array}$

a. Determined calorimetrically.

$b$. Measured two days after preparation. 
The alpha dose rate in the ${ }^{244} \mathrm{Cm}$ glass is $\sim 2400$ times, and in the ${ }^{238} \mathrm{Pu}$ glass $\sim 1060$ times, the initial rate calculated for glass containing composite SRP waste. These two factors increase rapidly with time because the calculated dose rate in SRP waste glass would decrease rapidly because of complete decay of some of the radionuclides.

Measured density of the glasses and a silicon standard are shown in Table 9. Variations with respect to the standard established that the change in glass densities may be significant statistically, but too slight $(20.05 \%)$ to affect waste form properties adversely.

TABLE 9

Measured Density of Glass Waste Forms at $21^{\circ} \mathrm{C}$

\begin{tabular}{|c|c|c|c|c|c|}
\hline $\begin{array}{l}\text { Age of } \\
\text { Test Glass, } \\
\text { days }\end{array}$ & $\begin{array}{l}\text { Equivalent } \\
\text { Containing } \\
244 \mathrm{~cm}\end{array}$ & $\begin{array}{l}\text { Age of Glass } \\
\text { SRP Waste, yr } \\
2{ }^{8}{ }^{8} \text { Pu }\end{array}$ & $\begin{array}{l}\text { Density, } \\
2{ }^{4} \mathrm{Cm}\end{array}$ & $\begin{array}{l}q / \mathrm{cm}^{3} \\
2^{38} \mathrm{Pu}\end{array}$ & Si std \\
\hline 2 & 14 & 6 & 3.0474 & 3.1164 & 2.3290 \\
\hline 40 & 9100 & 1100 & 3.0456 & 3.1153 & 2.3293 \\
\hline 42 & 10,000 & 1400 & 3.0453 & 3.1155 & 2.3292 \\
\hline 150 & $>10^{6}$ & - & 3.0399 & - & 2.3291 \\
\hline
\end{tabular}

The porosity of a nonradioactive glass of the same composition was estimated to be $<0.003 \%$ by scanning electron microscopy. No pores were detected at maximum magnification $(20,000 \mathrm{X})$, which would have shown pores as small as $\sim 7 \times 10^{4} \AA^{2}$ in a field of $\sim 3 \times 10^{9} \AA$ ? Calculations based on porosity and the amount of decay helium in the glass indicate that the tensile stress generated by SRP waste in a glass with this porosity will exceed $10 \mathrm{psi}$ only after $100 \mathrm{yr}$. In the test g1ass with ${ }^{244} \mathrm{Cm}$, which has not cracked after simulation of $>10^{6} \mathrm{yr}$, calculated tensile stress is $>2500$ psi. ${ }^{12}$

These results indicate that structural damage to glass waste forms containing alpha-bearing $\mathrm{SRP}$ waste should be minimal during several hundred years of storage.

\section{Devitrification of Glasses}

Glasses 18-35-1 and 18-45-3 were heated in air at $600^{\circ} \mathrm{C}$ for one month to determine the effects of prolonged heating. Powder X-ray diffraction showed that G1as 18-35-1 devitrified significantly and Glass 18-45-3 devitrified only slightly. 
Powdex $X-$ ray diffraction showed the crystalline phase in Glass 18-35-1 to be nepheline (NaAlSiO $\left.{ }_{4}\right)$, but did not identify conclusively the crystalline phase in 61 as $518-45 \mathrm{~m}$; possibilities include $\mathrm{MnFe}_{2} \mathrm{O}_{4}, \mathrm{Fe}_{2} \mathrm{TiO}_{4}, \mathrm{Mn}_{2} \mathrm{TiO}_{4}$, and $\mathrm{Mn}_{3} \mathrm{O}_{4}$. Nepheline has been reported previously in devitrified borosilicate glasses with high $\mathrm{Na}_{2} \mathrm{O}$ content. ${ }^{5}$ Gasses with high $\mathrm{Na}_{2} \mathrm{O}$ content were found to devitrify at $6600^{\circ} \mathrm{C}$ in a few hours. Electron photom micrographs of devitrified glasses are shown in Figure 4.

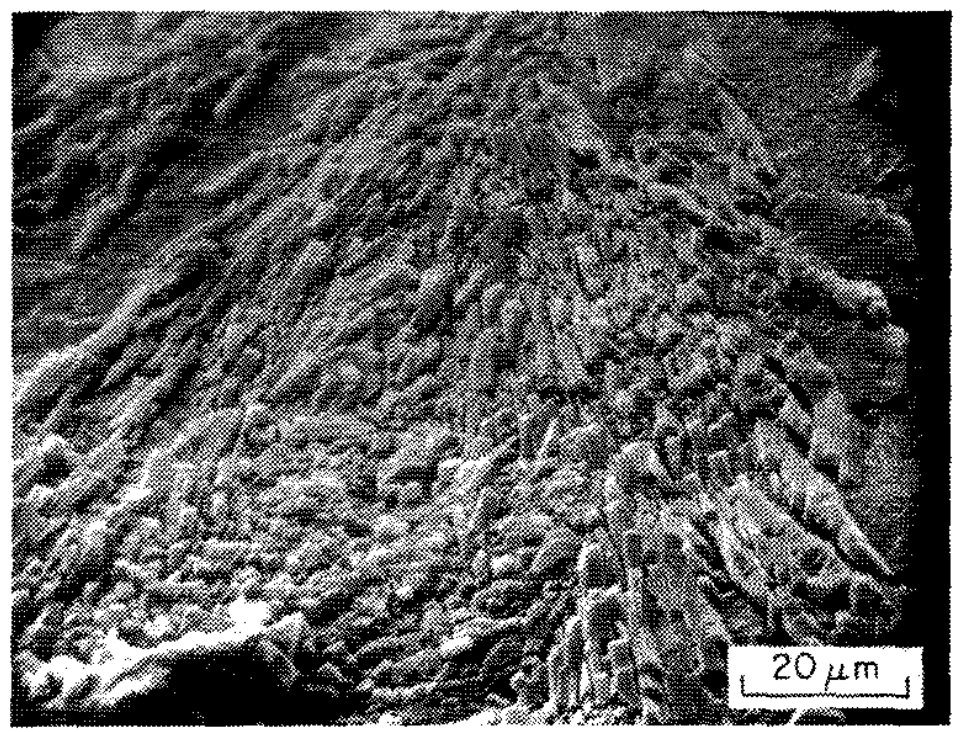

Glass 18-35-1

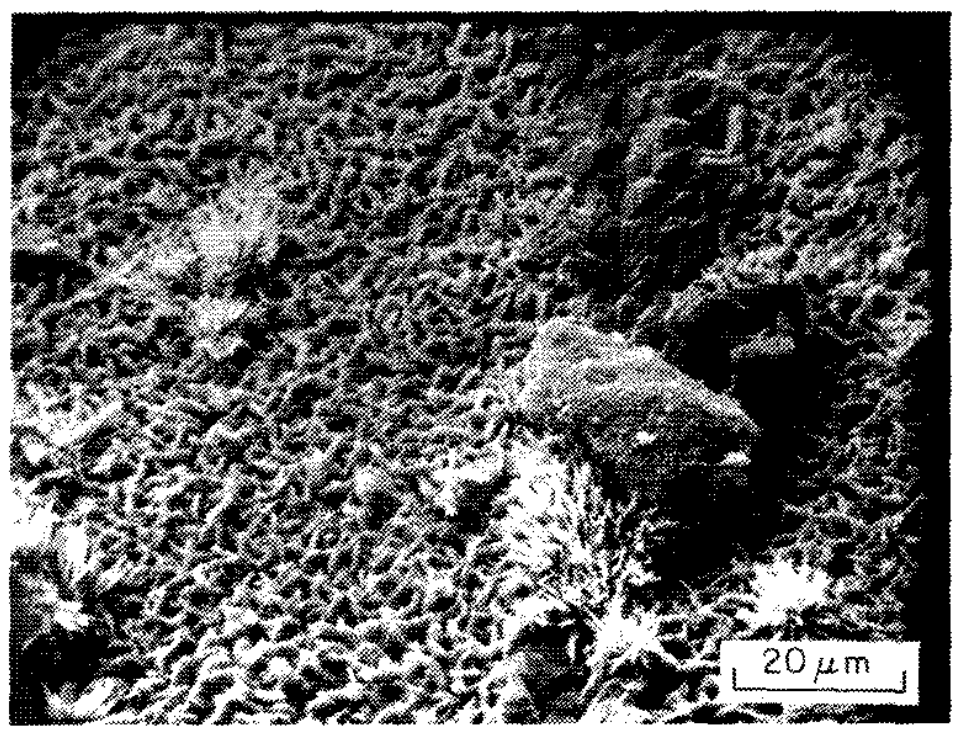

Glass $18-45-3$

FIGURE 4. Electron Photomicrographs of Devitrified Glasses 
Leachability of the devitrified glasses was determined at $\checkmark 99^{\circ} \mathrm{C}$ for $24 \mathrm{hr}$. Devitrification increased the sodium leach rates from $1.7 \times 10^{-4}$ to $5.0 \times 10^{-4} \mathrm{~g} /\left(\mathrm{cm}^{2}\right.$-day $)$ for 61 ass $18-35-1$, and from $3.3 \times 10^{-4}$ to $1.0 \times 10^{-3} \mathrm{~g} /\left(\mathrm{cm}^{2}\right.$-day $)$ for Glass $18-45-3$. These results are consistent with published data, ${ }^{2}$ which indicate that devitrification does not increase significantly the leachability of borosilicate glass. The crystalline phase, nepheline, is very insoluble; the increase in leachability has been attributed to leaching of the residual amomhous glass, 5 probably because of decrease of network formers. Leachability of phosphate glass increases a thousandfold with devitrification. ${ }^{2}$

Devitrification of Glasses $18-35-1$ and $18-45-3$ was also studied by differential themal analysis. As indicated in Figure 5, devitxification begins for both glasses at $2560^{\circ} \mathrm{C}$ and reaches a maximun rate at $615^{\circ} \mathrm{C}$. For Glass $18-35-1$, a second exothermic peak occurs at $745^{\circ} \mathrm{C}$. Crystalline products formed by extended heating at $745^{\circ} \mathrm{C}$ could not be identified by powder $x-$ ray diffraction.

These tests indicate that devitrification of glasses containing SRP sludge would be very slow. Even if devitrification occurred, leach rates would still be $410^{-6} \mathrm{~g} /\left(\mathrm{cm}^{2}\right.$ may).

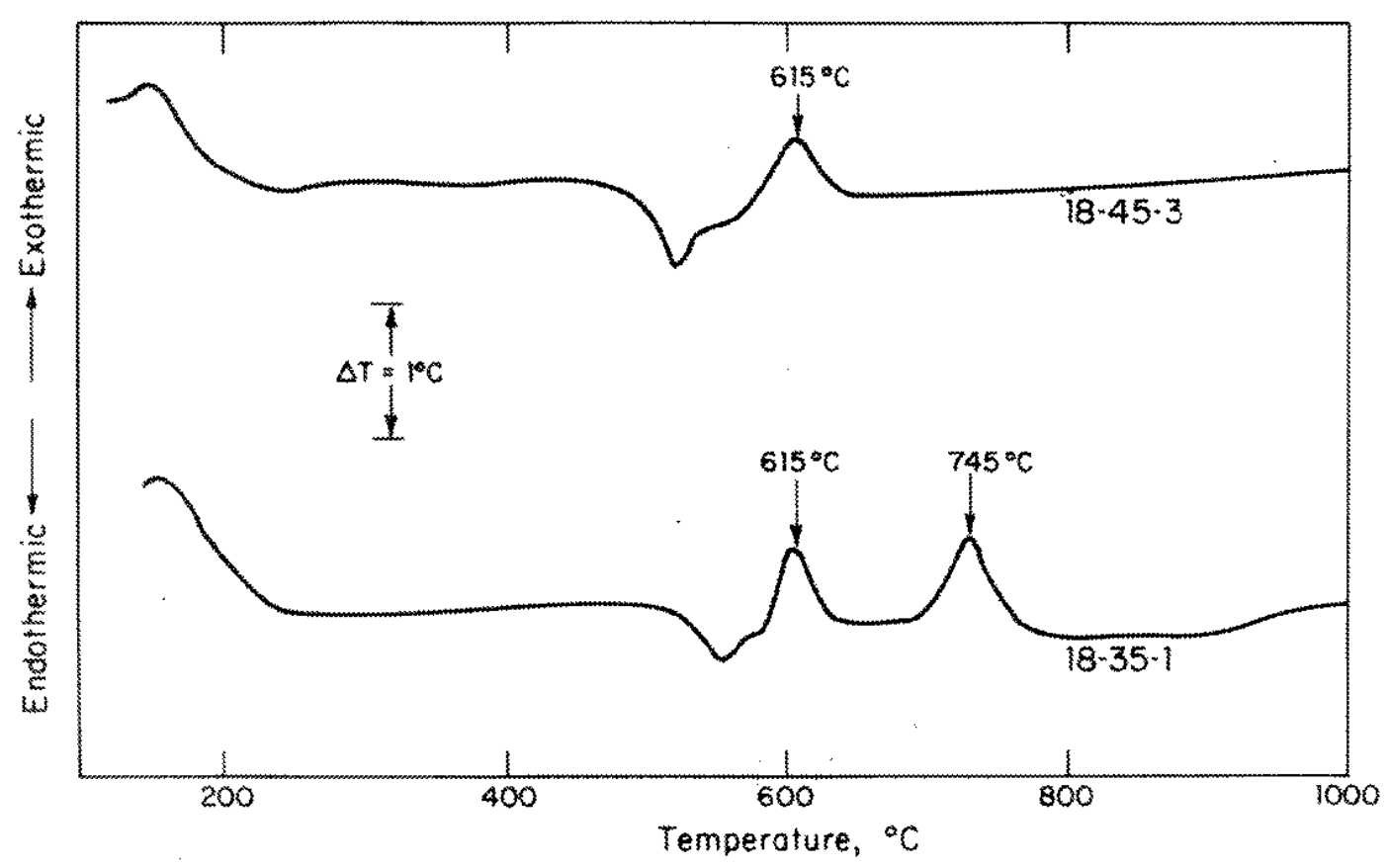

FIGURE 5. Differential Thermal Analysis of Glasses 18-45-3 and 18-35-1 


\section{Cesium Volatility During Glass Melting}

Tests were conducted to evaluate cesium volatility during glass melting. Other workers ${ }^{6}$ have shown that $\mathrm{B}_{2} \mathrm{O}_{3}, \mathrm{MOO}_{3}$, and $\mathrm{TiO}_{2}$ in a glass melt reduce cesium volatility (Figure 6). $\mathrm{TiO}_{2}$ is reported to be more desirable than $\mathrm{MoO}_{3}$ because $\mathrm{TiO}_{2}$ is more soluble in borosilicate glasses.

Tests were made with cesium-1oaded zeolite (using ${ }^{137} \mathrm{Cs}$ tracer) and with a mixture of Sludge III and cesium-loaded zeolite (Table 10). The apparatus shown in Figure 7 was used to determine cesium volatility. Most of the cesium that volatilized from the glass was deposited in the inverted funnel over the crucible. On $1 y \sim 10 \%$ of the cesium volatilized from the glass was deposited in the condenser and traps.

Tests 1 and 2 show that cesium volatility from cesium-loaded zeolite with no glass-forming additives is very low (0.01 to $0.03 \%)$. Tests 3 through 6 show that cesium volatility is not affected by the source of $\mathrm{B}_{2} \mathrm{O}_{3}$ and that $\mathrm{TiO}_{2}$ reduces cesium volatility. Tests 7 and 8 show that cesium volatility increases in the absence of $\mathrm{TiO}_{2}$. Tests 9 and 10 show that cesium volatility is low from sludge III and from a Sludge III cesium-zeolite mixture.

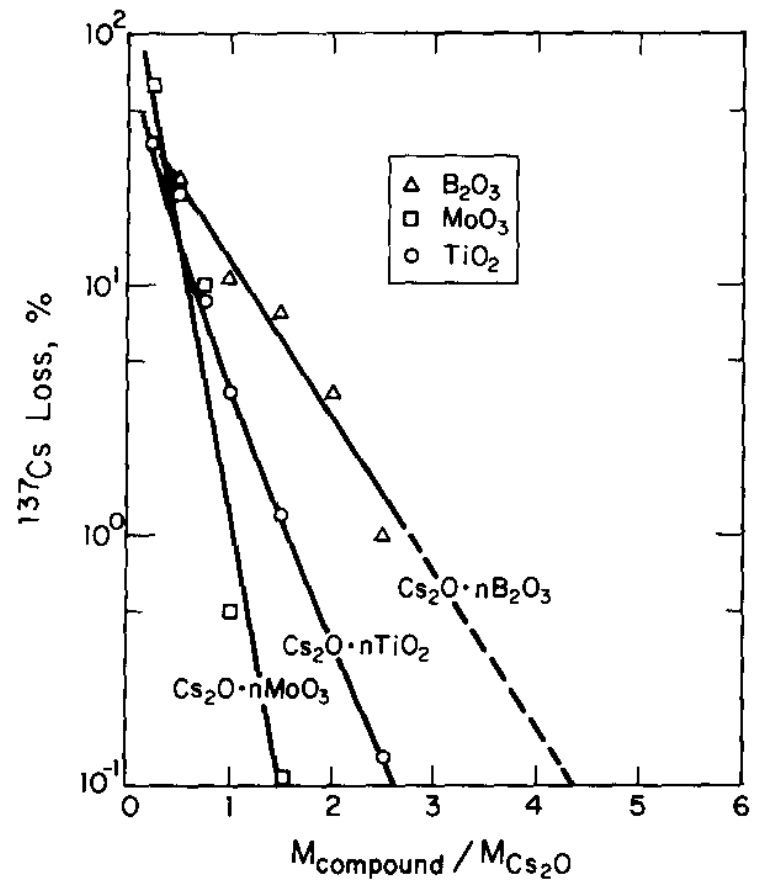

FIGURE 6. Loss of ${ }^{13^{7}} \mathrm{Cs}$ During Melting ( $1 \mathrm{hr}$ at $1000^{\circ} \mathrm{C}$ ) in the Presence of $\mathrm{B}_{2} \mathrm{O}_{3}, \mathrm{MoO}_{3}$, and $\mathrm{TiO}_{2}$ (from Reference 6) 
TABLE 10

Volatilization of Cesium During Glass Melting

(3 hr at $1150-1175^{\circ} \mathrm{C}$ )

\begin{tabular}{|c|c|c|c|c|c|c|c|c|}
\hline \multirow[b]{2}{*}{ Test } & \multicolumn{7}{|c|}{ Glass-Forming Components, wt \% } & \multirow{2}{*}{$\begin{array}{l}\text { Cesizm } \\
\text { Volatilized, \% }\end{array}$} \\
\hline & Zeolite & Studge III & $\mathrm{B}_{2} \mathrm{O}_{3}$ & $\mathrm{CaO}$ & $\mathrm{Na}_{2} \mathrm{O}$ & $\mathrm{TiO}_{2}$ & $\mathrm{SiO}_{2}$ & \\
\hline 1 & 100 & - & - & - & - & - & - & 0.01 \\
\hline 2 & 100 & - & - & - & - & - & - & 0.03 \\
\hline $3^{a}$ & 50 & - & 20 & 10 & 10 & 10 & - & 0.17 \\
\hline $4^{\alpha}$ & 50 & - & 20 & 10 & 10 & 10 & - & 0.43 \\
\hline $5^{b}$ & 50 & - & 20 & 10 & 10 & 10 & - & 0.26 \\
\hline $6^{b}$ & 50 & - & 20 & 10 & 10 & 10 & - & 0.47 \\
\hline 7 & 55.1 & - & 22.5 & 11.2 & 11.2 & - & - & 1.35 \\
\hline 8 & 55.1 & - & 22.5 & 11.2 & 11.2 & - & - & 1.03 \\
\hline 9 & - & 45 & 5.5 & 2.8 & 12.4 & 5.5 & 28.8 & 0.21 \\
\hline 10 & 10 & 35 & 5.5 & 2.8 & 12.4 & 5.5 & 28.8 & 0.55 \\
\hline
\end{tabular}

a. $\mathrm{B}_{2} \mathrm{O}_{3}$ supplied by $\mathrm{H}_{3} \mathrm{BO}_{3}$

b. $\mathrm{B}_{2} \mathrm{O}_{3}$ and $\mathrm{Na}_{2} \mathrm{O}$ supplied by $\mathrm{Na}_{2} \mathrm{~B}_{4} \mathrm{O}$,

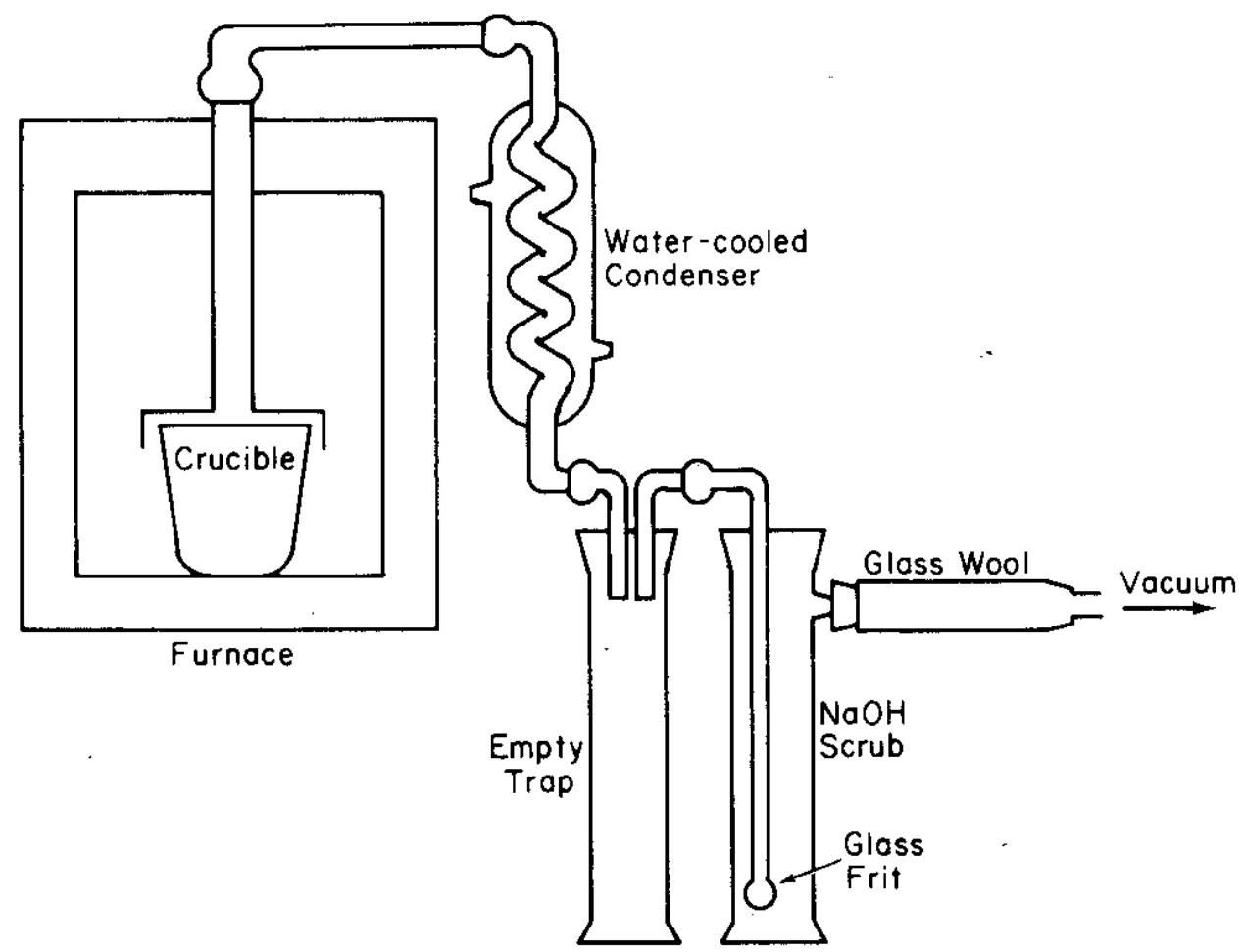

FIGURE 7. Volatility Apparatus 
Ruthenium Volatility During Glass Melting

Ruthenium volatility during glass melting was measured. Other workers ${ }^{6}$ have shown that ruthenium volatility is mainly a function of nitrate concentration in the glass mix (Figure 8). Nitrate oxidizes ruthenium to volatile $\mathrm{RuO}_{4}$ during melting.

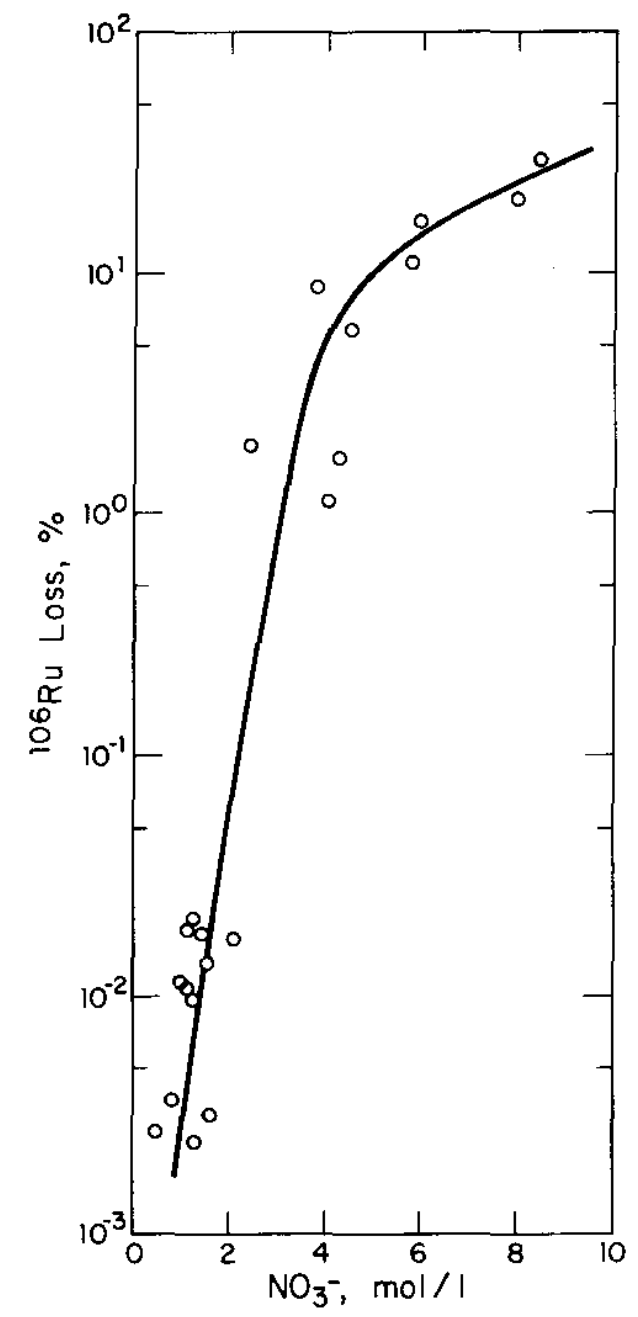

FIGURE 8. Loss of ${ }^{106} \mathrm{Ru}$ as a Function of the Nitrate Concentration in Glass Melt (from Reference 6)

Tests were made with the same apparatus (Figure 7) used for evaluation of cesium volatility (Table 11). ${ }^{106} \mathrm{Ru}$ tracer was added to the glass mix as a dilute caustic nitrite solution. 
Tests were made with both Sludge I and Sludge III at various nitrate concentrations. The glass mix was heated for $3 \mathrm{hr}$ at 1150 to $1175^{\circ} \mathrm{C}$. As in the cesium tests, most of the ruthenium that volatilized from the glass mix was deposited in the inverted funnel over the crucible.

\section{TABLE 11}

Volatility of Ruthenium during Glass Melting ( $3 \mathrm{hr}$ at 1150 to $1175^{\circ} \mathrm{C}$ )

$\begin{array}{llll}\text { Test Number } & \text { Sludge Type } & \text { Wt \% Nitrate } & \% \text { Ru Volatilized } \\ 1 & \text { I (Fe-Al) } & 1 & 10.1 \\ 2 & \text { I (Fe-A1) } & 5 & 27.1 \\ 3 & \text { I (Fe-A1) } & 10 & 29.6 \\ 4 & \text { II I (Fe-Mn) } & 0 & 50.3 \\ 5 & \text { II I (Fe-Mn) } & 10 & 54.7\end{array}$

These results indicate that nitrate in the glass mix containing Sludge I affects ruthenium volatility, but not as much as does $\mathrm{MnO}_{2}$ in Sludge III. Apparently $\mathrm{MnO}_{2}$ oxidizes ruthenium to $\mathrm{RuO}_{4}$ more effectively than does nitrate.

\section{Mercury Volatility During Glass Melting}

The temperature and nature of mercury volatilization during glass melting were studied using the apparatus shown in Figure 7 . In these tests, $40 \%$ Sludge II, which-contains 20 wt HgO, was melted with Mix 18. During melting, meta11ic mercury was observed in the horizontal tube of the volatility apparatus at $\sim 580^{\circ} \mathrm{C}$ and continued to volatilize at higher temperatures.

Volatilization of metallic mercury from Sludge II was also studied by thermogravimetric analysis. Mercury began to volatilize at $\sim 350^{\circ} \mathrm{C}$ and continued to $\sim 600^{\circ} \mathrm{C}$. No plugging problems were encountered.

\section{Sulfate Solubility in Glass}

The solubility of sulfate in glasses containing simulated SRP sludges was determined. SRP sludge contains sulfate, and published data ${ }^{4,13}$ indicate that sulfates are not compatible with borosilicate glasses - a second phase segregates during melting. The segregated sulfate phase is highly leachable and rich in cesium. 
Various sulfates ( $\mathrm{Ba}, \mathrm{Na}$, and $\mathrm{Nd}$ ) were mixed in Glasses 18-35-1 and 18-45-3, melted for $3 \mathrm{hr}$ at $1150^{\circ} \mathrm{C}$, and then cooled in a graphite mold. In some cases, a sulfate phase formed on the surface of the glass and could be dissolved easily with water. The types and amounts of sulfate incorporated into the glass is given in Table 12. Amounts of sulfate actually dissolved in the glass were not determined; the amount of sulfate added to the glass mixes was increased until a separate sulfate phase formed on the glass surface, indicating that the solubility had been exceeded.

TABLE 12

Solubility of Sulfates in Glass

$\left(1150^{\circ} \mathrm{C}\right.$ for $\left.3 \mathrm{hr}\right)$

$\begin{array}{lll}\text { Glass } & \begin{array}{l}\text { Sulfate } \\ \text { Cation }\end{array} & \begin{array}{l}\text { Solubility of } \\ \text { Sulfate, wt \% }\end{array} \\ 18-35-1 & \mathrm{Ba} & 1.12 \\ 18-45-3 & \mathrm{Ba} & 0.90 \\ 18-45-3 & \mathrm{Na} & 0.90 \\ 18-45-3 & \mathrm{Nd} & 0.79\end{array}$

Solubility limits for $\mathrm{BaSO}_{4}$ and $\mathrm{Na}_{2} \mathrm{SO}_{4}$ are the same, but $\mathrm{Nd}_{2}\left(\mathrm{SO}_{4}\right)_{3}$ is slightly less soluble. This small difference may not be significant because $\mathrm{Nd}_{2}\left(\mathrm{SO}_{4}\right)_{3}$ is less thermally stable than $\mathrm{Na}_{2} \mathrm{SO}_{4}$ and would be expected to decompose during prolonged heating at $1150^{\circ} \mathrm{C} .^{14}$ At $1150^{\circ} \mathrm{C}$, most sulfates expected in SRP waste sludge would convert to $\mathrm{Na}_{2} \mathrm{SO}_{4}$ in the glass melt. $\mathrm{Na}_{2} \mathrm{SO}_{4}$ is thermally stable and evaporates congruently from a glass me1t at $\sim 1400^{\circ} \mathrm{C}$. Potassium, rubidium, and cesium sulfates are more thermally stable than $\mathrm{Na}_{2} \mathrm{SO}_{4}$ or other common sulfates. The high thermal stability of $\mathrm{Cs}_{2} \mathrm{SO}_{4}$ could explain the cesium-rich sulfate phase segregated from borosilicate glasses.

\section{Compressive Strengths of Glasses}

In order to compare the strength of glass to other waste forms being studied at SRL, the compressive strengths of glass products containing simulated SRP sludges were measured. Cylinders, 0.5-in. diameter by 1-in. long, were made with Glasses 18-35-1 and 18-45-3. The cylinder ends were cut parallel and polished, and breaking strengths were determined with a hydraulic press.

Compressive strengths for both glasses were $85,000 \pm 20,000$ psi. Both shattered into small fragments upon breaking. These 
results show that glass waste forms would be much stronger than some other types, such as concrete.

\section{Effect of $\mathrm{Li}_{2} \mathrm{O}$ on Glass Viscosity}

Since aluminum in Sludge I limits the amount that can be incorporated into Mix 18 , tests were made to determine the effects of substituting $\mathrm{Li}_{2} \mathrm{O}$ for $\mathrm{Na}_{2} \mathrm{O}$. Other workers ${ }^{15}$ have shown that a $\mathrm{Li}_{2} \mathrm{O}-\mathrm{Na}_{2} \mathrm{O}$ mixture results in a lower viscosity melt than either pure oxide.

About 0.2 to $4.0 \% \mathrm{Li}_{2} \mathrm{O}$ was substituted for the same amount of $\mathrm{Na}_{2} \mathrm{O}$ in the Glass $18-35-1$, and the glasses were melted at $1150^{\circ} \mathrm{C}$. Qualitative comparisons of me1t viscosities were made by observing ease of pouring. The glasses were also leached by the Soxhlet method to determine effects of $\mathrm{Li}_{2} \mathrm{O}$ on leachability.

Melt viscosity decreased as more $\mathrm{Li}_{2} \mathrm{O}$ was substituted. Viscosity of Glass 18-45-1 with $4 \% \mathrm{Li}_{2} \mathrm{O}$ substituted for $\mathrm{Na}_{2} \mathrm{O}$ was approximately the same as the viscosity of Glass 18-35-1 with no $\mathrm{Li}_{2} \mathrm{O}$. In previous tests, Glass 18-45-1 had to be heated to $1400^{\circ} \mathrm{C}$ to be easily poured.

$\mathrm{Li}_{2} \mathrm{O}$ had a slight detrimental effect on leachability. With $4 \% \mathrm{Li}_{2} \mathrm{O}$ substituted for $\mathrm{Na}_{2} \mathrm{O}$ in Glass $18-35-1$, the leach rate increased $\sim 30 \%$.

These results show that small amounts of $\mathrm{Li}_{2} \mathrm{O}$ can be substituted for $\mathrm{Na}_{2} \mathrm{O}$ in a glass $\mathrm{mix}$ to reduce melt viscosity.

\section{CONCLUSIONS AND FUTURE WORK}

This work demonstrated that SRP waste can be solidified as a low-leachable, strong, borosilicate glass by melting with appropriate glass formers at $1150^{\circ} \mathrm{C}$. Sludge content would be $\leq 45$ wt $\%$, depending on the amount of aluminum and sulfate in the sludge. An off-gas system would be required for removing volatilized cesium, ruthenium, and mercury. The effects of gamma radiation, alpha decay, and devitrification during prolonged storage would be insignificant.

In future work, actual SRP waste will be incorporated into glass. Sludge contents will be as high as aluminum and sulfate permit. The extent of cesium and ruthenium volatilization during melting will be determined. $\mathrm{Li}_{2} \mathrm{O}$ wi 11 be added to the glass mix if high-viscosity melts are encountered. Products will be characterized by leachability at ambient temperature. The effects of extended storage at elevated temperature will also be evaluated. 


\section{REFERENCES}

1. R. M. Wallace, H. L. Hull, and R. F. Bradley. Solid Forms for Savannah River Plant High-Level Waste. USAEC Report DP-1335, Savannah River Laboratory, E. I. du Pont de Nemours and Co., Aiken, SC (1974).

2. J. E. Mende 1 and J. L. McElroy. Waste Solidification Progrom Volume 20, Evaluation of Solidified Waste Products. USAEC Report BNWL-1666, Batte1le Northwest Laboratories, Rich1and, WA (1972).

3. J. R. Grover and B. E. Chidley. Glasses Suitable for the Long Term Storage of Fission Products. British Report AERE-R-3178 Atomic Energy Research Establishment, Harwe11, England (1960).

4. W. Bocola, A. Donato, and G. Sgalambro. "Survey of the Present State of Studies on the Solidification of Fission Product Solutions in Italy". p. 449 in Symposium on the Management of Radioactive Wastes from Fuel Reprocessing, IAEA, Paris (1972).

5. W. Heimerl, et al. Research on Glasses for Fission Product Fixation. HMI-B109, Hahn-Meitner Institute, Berlin, Germany (1971).

6. G. Rudolph, et a1. "Lab-scale $R+D$ work on Fission Products Solidification by Vitrification Processes". p. 655 in Symposium on the Monagement of Wastes from Fuel Reprocessing, IAEA, Paris (1972).

7. J. L. McElroy and J. E. Mendel. "Radioactive Waste Management. Report of Visit to England, Germany, and France". Pacific Northwest Laboratory, Richland, WA (1973).

8. J. R. Grover. "Glasses for Fixation of High Level Radioactive Wastes." p. 593 in Symposium on the Management of Wastes from Euel Reprocessing, IAEA, Paris (1972).

9. S. P. Faile and D. M. Roy. "Solubilities of Ar, $\mathrm{N}_{2}, \mathrm{CO}_{2}$, and $\mathrm{He}$ in $\mathrm{Gl}$ asses at Pressures to 10 Kbars." J. Am. Cer. Soc. 49,638 (1966).

10. H. A. Elliot. "An Analysis of the Conditions for Rupture Due to Griffith Cracks." Proc. Phys. Soc. 59, 208 (1947). 
11. D. F. Newman and D. C. Quimly. Quarteriy Progress Report, Waste Fixation Program, July-Sept. 1973 USAEC Report BNWL-1788, p 39, Battelle-Northwest Laboratories, Rich1and, WA (1973).

12. W. A. Ross and D. F. Newman in Research and Development Activities Waste Fixation Program, Quarterly Progress Report, October-December 1973. USAEC Report BNWL-1809, p 48, Battelle-Northwest Laboratories Richland, WA (1974).

13. N. S. Sunder Rajan, M. S. Kumra, and K. T. Thomas. "Waste Immobilization Plant at Tarapur - A Survey of Process and Design Features". p. 683 in Symposizm on the Monagement of Radioactive Wastes from Fuel Processing. IAEA, Paris (1972).

14. K. H. Stern and E. L. Weise. High Temperature Properties and Decomposition of Inorganic Salts Part 1. Sulfates. NSRDS-NBS 7, National Bureau of Standards, Washington, DC (1966).

15. H. W. Godbee, W. E. Clark, and C. L. Fitzgerald. "Physical Properties of Solids Incorporating Simulated Radioactive Wastes"! p. 566 in Proceedings of the Symposium on the Solidification and Long-Term Storage of Highly Radioactive Wastes, Richland, Washington, February 14-18, 1966. USAEC Report CONF-660208, Technical Information Center, Oak Ridge, TN (1966). 